\title{
Endogenous erythropoietin level and effects of exogenous erythropoietin in a rat model of blunt chest trauma-induced pulmonary contusion
}

\author{
Vedat Bakan, M.D.,' Ergül Belge Kurutaş, M.D.,, Harun Çıralık, M.D.,, \\ Mustafa Gül, M.D., ${ }^{4}$ Ahmet Çelik, M.D. ${ }^{2}$
}

\begin{abstract}
1Department of Pediatric Surgery, Esenler Women and Children Diseases Hospital, İstanbul2Department of Biochemistry, Sütçü Imam University Faculty of Medicine, Kahramanmaraş${ }^{3}$ Department of Pathology, Sütçü İmam University Faculty of Medicine, Kahramanmaraş${ }^{4}$ Department of Microbiology, Sütçü İmam University Faculty of Medicine, Kahramanmaraş-
\end{abstract}

\begin{abstract}
BACKGROUND: The present objective was to investigate endogen erythropoietin (EPO) level and relationship to oxidative stress within the first 24 hours of blunt chest trauma-induced pulmo-nary contusion (PCn) in a rat model.

METHODS: Thirty-five rats were divided into 3 groups. In the baseline control group $(B C, n=7)$, rats were uninjured and untreated. In the positive control group $(P C, n=2 I)$ rats were injured but untreated. In the EPO-24 group $(n=7)$, rats were injured and a single dose of intra-peritoneal EPO (5000 IU/ $/ \mathrm{kg})$ was administered immediately after lung injury. The PC group was divided into 3 subgroups: PC-6 $(n=7), P C-12(n=7)$, and PC-24 ( $n=7)$. The BC group was subjected to thoracotomy, and the right lung was harvested. The PC subgroups were eu-thanized at 6, 12, and 24 hours after injury, respectively. The EPO-24 group was euthanized at the $24^{\text {th }}$ hour after injury. Lung samples were obtained, levels of malondialdehyde (MDA) and EPO were analyzed, and activities of superoxide dismutase (SOD) and catalase (CAT) were then measured in homogenized lung tissue samples. Histologic damage to lung tissue in the BC group, the EPO24 group, and PC subgroup euthanized at the $24^{\text {th }}$ hour after injury were scored by a single pathologist blinded to group assignation.
\end{abstract}

RESULTS: Mean MDA levels, as well as SOD and CAT activities, of the BC and EPO-24 groups were significantly lower than those of the PC group $(p<0.005)$. Mean EPO concentra-tion of the PC group was significantly higher than that of the $B C$ group $(P<0.005)$. Lung tis-sue damage scores measured at 24 hours after injury were significantly lower in the EPO-24 group than in the PC group ( $<<0.005)$.

CONCLUSION: In the present PCn rat model, EPO concentrations, as well as SOD and CAT levels, were high in lung tissue, when measured at 24 hours after PCn. When administered early after chest trauma, EPO significantly attenuated oxidative damage and tissue damage in the early phase, as assessed by biochemical markers and histologic scoring.

Keywords: Contusion; erythropoietin; lung injury; oxidative stress.

\section{INTRODUCTION}

Pulmonary contusion ( $P C n$ ) is the result of kinetic energy transmitted to the pulmonary pa-renchyma, and is defined

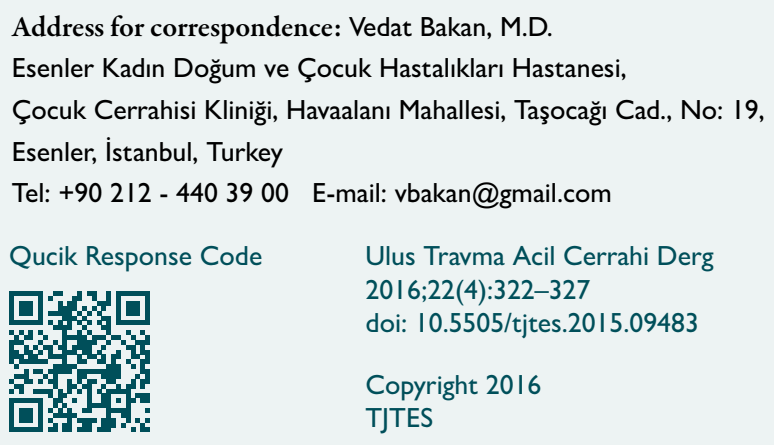

as pulmonary parenchymal damage caused by chest trauma in the absence of associated pulmonary laceration. PCn frequently occurs following chest injury, particularly in pediatric patients. Injury to lung tissue results in hemorrhage, edema, inflam-mation, and alveolar collapse. ${ }^{[1,2]}$ However, the exact mechanism of tissue injury has yet to be understood. A variety of pathophysiological alterations are present in cases of PCn, including inflammation, increased alveolocapillary permeability, pulmonary edema, increased intrap-ulmonary shunting, and loss of compliance, resulting in alveolar collapse, ventilation-perfusion mismatch, and hypoxemia. ${ }^{[2-4]}$

In addition, PCn may be the result of oxidative stress and progressive inflammatory response. Reactive oxygen species (ROS) released by both leukocyte and macrophages after blunt chest trauma contribute to tissue damage. Although 
antioxidants have been widely tested as treat-ment for blunt chest trauma-related PCn, no standard pharmacological therapy yet exists. ${ }^{[3-6]}$

Erythropoietin (EPO) is a hypoxia-inducible hematopoietic growth factor with antiapoptotic, antioxidant, anti-inflammatory, angiogenic, and neuroprotective effects. Hypoxia is the main stimulus for EPO production; in fact, EPO synthesis may increase 50-100-fold in severely hypoxic conditions. ${ }^{[5,6]}$ EPO is induced via hypoxia-inducible factors such as HIF-I. Hypoxic preconditioning and non-hypoxic inflammatory mediators, including ROS, have been found to increase levels of HIF-I. ${ }^{7,8]}$ EPO has also been found to attenuate ischemia/reperfusion (I/R)-induced lung injury, ${ }^{[9]}$ as well as tracheobronchial and pulmonary type II epithelial in-jury following traumatic brain injury. ${ }^{[3]}$

In light of the results mentioned above, the present aim was to determine effects of EPO on lung tissue following blunt chest injury-induced $\mathrm{PCn}$ in a rat model.

\section{MATERIALS AND METHODS}

\section{Animals}

Following approval from the Ethics Committee on Animal Research of the present medical faculty, 35 male Sprague-Dawley rats, weighing 300-330 g each were selected and acclimatized for 10 days in the animal laboratory of the research center, receiving a standard diet and water ad libitum.

\section{Blunt Chest Trauma}

PCn was induced by method of Raghavendran et al. ${ }^{[10]} \mathrm{A}$ hollow, 300-g cylindrical weight encased in a vertical stainless steel tube was dropped from $40 \mathrm{~cm}$, positioned on a Lexon plat-form resting on the rat's chest. The platform was suspended on Teflon guides, in order to min-imize friction and facilitate energy transfer to the animal. The platform was attached to a plas-tic protective shield in direct contact with the lateral aspect of the rat. This precordial shield was designed to protect the heart from contusion, directing impact energy to the lateral sec-tions of the chest. Impact energy, $E$ (in joules) was calculated using the equation $E=m g h$, in which $\mathrm{m}$ signifies mass of the cylindrical weight $(0.3 \mathrm{~kg}), \mathrm{g}$ signifies gravitational accelera-tion $\left(9.8 \mathrm{~m} / \mathrm{s}^{2}\right)$, and $\mathrm{h}$ signifies height of the weight above the Lexon platform $(0.4 \mathrm{~m})$. Thus, total energy transferred to the chest wall of the rat was $1.17 \mathrm{~J}$.

\section{Experimental Design}

Rats were divided into 3 groups. The baseline control group $(B C, n=7)$ was uninjured and un-treated. The positive control group (PC, $n=21$ ) was injured but untreated, and the EPO-24 group $(n=7)$ was injured and administered EPO. The PC group was divided into 3 subgroups: PC-6 $(n=7), P C-12(n=7)$, and PC-24 ( $n=7)$. Rats were anesthetized with $60 \mathrm{mg} / \mathrm{kg}$ of intraperitoneal ketamine hydrochloride (Ketalar; Eczacıbaşı AŞ, İstanbul, Turkey). Blunt chest trauma was administered. Im- mediately after the trauma, EPO-24 rats were given a single dose of Eprex intraperitoneal EPO (5000 U/kg; Janssen-Cilag AG, Sihlbruggstrasse, Switzerland). Analgesia was provided by morphine sulphate $(0.05 \mathrm{mg} / \mathrm{kg})$ intraperitoneally administered. Following the procedure, all rats were transferred to their cages. The PC-6, PC-12, or PC-24 groups were euthanized by decapitation 6,12 , or 24 hours after chest trauma, respectively. The BC and EPO-24 groups were euthanized by decapitation 24 hours after chest trauma. The right lung was harvested from rats in the BC, PC, and EPO-24 groups. The upper lobes of rats in the BC and EPO-24 groups, as well as those in the PC-24 subgroup were fixed in 10\% formaldehyde for histopathological examination. The middle and lower lobes were stored at $-8^{\circ} \mathrm{C}$ until biochemical and EPO assays were performed.

\section{Biochemical Analysis}

Levels of malondialdehyde (MDA), and activities of superoxide dismutase (SOD) and cata-lase (CAT) were measured in the following fashion. Tissue samples were homogenized with 3 volumes of ice-cold I.15\% potassium chloride. Activities of antioxidant enzymes (CAT, SOD), and MDA levels were measured in the supernatant obtained after centrifugation at 14000 rpm. SOD activity was measured in the tissue samples according to the method de-scribed by Fridovich. ${ }^{[1]}$ This method employs xanthine and xanthine oxidase to generate superoxide radicals, which react with $\mathrm{p}$-iodonitrotetrazolium violet (INT) to form a red form-azan dye measured at 505 $\mathrm{nm}$. The assay medium consisted of $0.01 \mathrm{M}$ phosphate buffer, CAPS (3-cyclohexylamino-I-propane sulfonic acid) buffer solution (50 mM CAPS, $0.94 \mathrm{mM}$ EDTA, saturated $\mathrm{NaOH}$ ) at a $\mathrm{pH}$ of 10.2 , solution of substrate $(0.05 \mathrm{mM}$ xanthine, 0.025 $\mathrm{mM}$ INT), and $80 \mathrm{UL}$ xanthine oxidase. SOD activity was expressed as $U / \mathrm{mg}$ protein.

CAT activity was determined by measuring the decrease in hydrogen peroxide concentration at $230 \mathrm{~nm}$ by the method of Beutler. ${ }^{[12]}$ The assay medium consisted of I-M Tris hydrochlo-ride, 5-mM buffer solution ( $\mathrm{pH} 8.0$ ), $10 \mathrm{mM} \mathrm{H}_{2} \mathrm{O}_{2}$, and the tissue sample, to make a final vol-ume of $1.0 \mathrm{~mL}$. CAT activity was expressed as $\mathrm{U} / \mathrm{mg}$ protein. Tissue sample protein concen-tration was measured with a spectrophotometer by the method of Lowry. ${ }^{[13]}$ MDA levels in tissue samples were measured using the 2-thiobarbituric acid (TBA) test. ${ }^{[14]}$ The reaction mixture contained a $0.1-\mathrm{mL}$ sample, $0.2 \mathrm{~mL}$ of $8.1 \%$ sodium dodecyl sulphate, $1.5 \mathrm{~mL}$ of $20 \%$ acetic acid, and 1.5 $\mathrm{mL}$ of an $0.8 \%$ aqueous solution of TBA. The $\mathrm{pH}$ of the mixture was adjusted to 3.5 , and the volume was increased to 4.0 $\mathrm{mL}$, by means of distilled water, and $5.0 \mathrm{~mL}$ of $\mathrm{n}$-butanol and pyridine mixture (I5:I; v/v) was then added. The mixture was shaken vigorously. After centrifugation at $4000 \mathrm{rpm}$ for 10 min, absorbance of the organic layer was $532 \mathrm{~nm}$.

\section{Measurement of Tissue EPO Levels}

Tissue EPO concentrations were measured with a commer- 
Table I. Biochemical parameters and tissue damage scores in groups (mean $\pm S D)$

\begin{tabular}{|c|c|c|c|c|c|}
\hline \multirow[t]{3}{*}{ Parameters } & \multicolumn{5}{|c|}{ Groups } \\
\hline & \multirow{2}{*}{$\begin{array}{l}\text { BC (baseline } \\
\text { control, } n=7 \text { ) }\end{array}$} & \multicolumn{3}{|c|}{ PC (positive control, $n=2 I$ ) } & \multirow{2}{*}{$\begin{array}{c}\text { EPO-24 (erythropoietin } \\
\text { treated, } n=7 \text { ) }\end{array}$} \\
\hline & & PC-6 $(n=7)$ & $P C-12(n=7)$ & PC-24 $(n=7)$ & \\
\hline MDA (nmol/mg protein) & $4.5 \pm 1.8$ & $32.3 \pm 5.8^{\mathrm{a}}$ & $33.4 \pm 5.3^{\mathrm{a}}$ & $38.4 \pm 13.4^{\mathrm{a}}$ & $5.8 \pm 1.6$ \\
\hline CAT (U/mg protein) & $32.8 \pm 5.7$ & $75.4 \pm 22.7^{\mathrm{a}}$ & $71.5 \pm 18.3^{\mathrm{a}}$ & $62.5 \pm 19.5^{\mathrm{a}}$ & $35.2 \pm 15.1$ \\
\hline SOD (U/mg protein) & $12.5 \pm 1.6^{\mathrm{b}}$ & $13.0 \pm 1.5$ & $18.4 \pm 1.6^{\mathrm{a}}$ & $21.5 \pm 5.6^{\mathrm{a}}$ & $12.4 \pm 1.6$ \\
\hline Tissue erythropoietin $(\mathrm{ng} / \mathrm{mL})$ & $8.4 \pm 5.9^{b}$ & $24 I .2 \pm 46.1$ & $240.1 \pm 40.1$ & $239.1 \pm 58.2$ & $302.0 \pm 51.5$ \\
\hline Tissue damage score & $0.00 \pm 0.00$ & - & - & $10.5 \pm 2.1^{c}$ & $5.1 \pm 1.3$ \\
\hline
\end{tabular}

MDA: Malondialdehyde; CAT: Catalase; SOD: Superoxide dismutase.

Groups were baseline control = uninjured and untreated, positive control = injured but untreated, erythropoietin-treated = injured and given a single dose of IP erythropoietin just after lung injury. All rats of EPO-24 group were killed at hour 24 after chest trauma. Rats of PC-6, PC-12, and PC-24 groups were killed at hour 6 , 12 , and 24 after chest trauma, respectively.

a: $p<0.005$ vs baseline control and erythropoietin treated groups. b: $p<0.005$ vs positive control and erythropoietin treated groups. c: $p<0.005$ vs erythropoietin treated group.

cial kit using the ELISA method (Rat EPO ELISA kit, Cusabio Biotech Co. Ltd., Wuhan Hubei, China). Tissue homogenates were prepared as follows: $100 \mathrm{mg}$ of tissue was rinsed with Ix phosphate buffered solution (PBS), and was homogenized in $\mathrm{I} \mathrm{mL}$ of $\mathrm{IxPBS}$, then stored overnight at $-20^{\circ} \mathrm{C}$. After 2 freeze-thaw cycles were performed to break cell membranes, homogenates were centrifuged for 5 minutes at $5000 \mathrm{rpm}$. The supernate was immediately removed then tested.

\section{Histopathological Evaluation}

Tissue samples were fixed in 10\% neutral buffered formalin solution and embedded in paraf-fin. At least 8 tissue sections of 5 - $\mu \mathrm{m}$ thickness were obtained, then stained with haematoxy-lin-eosin and scored by a single pathologist blinded to group distribution. Each specimen was scored for congestion (vascular dilation), hemorrhage, interstitial edema, and alveolar col-lapse on a scale from $0-3$, in which 0 signified absence of pathology ( $<5 \%$ of maximum pa-thology), I signified mild (5-10\% of maximum pathology), 2 signified moderate (II$20 \%$ of maximum pathology), and 3 signified severe pathology ( $>21 \%$ of maximum pathology). The specimen was scored for inflammation as follows: 0 signified no extravascular leukocytes, I signified < 10 leukocytes, 2 signified 10-45 leukocytes, and 3 signified $>45$ leukocytes. Total tissue damage was calculated using the scoring system described above. ${ }^{[15]}$

\section{Statistical Analysis}

Individual group biochemical parameters were checked for normalcy of distribution prior to statistical analysis using the Shapiro-Wilk test. The Kruskal-Wallis test was used for nonnormally distributed variables, and Mann-Whitney $U$ test was performed on biochemical data to examine differences among groups. Tissue damage scores were compared using the Mann-Whitney $U$ test. Data were expressed as mean $\pm S D$. Results with $p<0.005$ were considered sta-tistically significant.

\section{RESULTS}

\section{Biochemical Findings}

Test protocol was successfully implemented in all animals. Lung tissue MDA levels, SOD and CAT activities, EPO concentrations, and total tissue damage scores are listed in Table I. All biochemical parameters were significantly different between the PC and EPO groups $(p<0.005)$. MDA levels, and CAT and SOD activities were significantly lower in the $B C$ and EPO groups, compared to the PC group $(p<0.005)$. MDA levels and EPO concentrations were significantly higher in the PC-6, PC-12, and PC-24 subgroups, compared to the BC group ( $p<0.005$; Fig. I). MDA levels in the EPO group were similar to those of the BC group, sug-gesting that MDA levels returned to normal range (Table I, Fig. I).

\section{Histopathological Findings}

Congestion, edema, and alveolar collapse were more prominent in the PC-24 subgroup spec-imens, compared to the $B C$ and EPO-24 group specimens. Total tissue damage scores corre-lated with MDA levels. Total lung tissue damage score of the EPO-24 group was lower than that of the PC-24 group $(P<0.005)$; they were generally grade 0 and $I$ in the EPO-24; grade I and 2 in the PC-24 group. Lungs from the BC group were normal in histopathological appear-ance (Fig. 2).

\section{DISCUSSION}

Results of present study demonstrate that blunt chest trauma caused oxidative stress evi-denced by biochemical changes. MDA levels were approximately 8 times higher in untreated traumatized rats, compared to non-traumatized and EPOtreated rats. EPO administration also resulted in lower levels of MDA, a marker of hypoxic tissue injury, compared to traumatized rats not administered EPO. Similar to the present results, Türüt et al. ${ }^{[15]}$ and Basaran et al..$^{[1]]}$ found significantly 


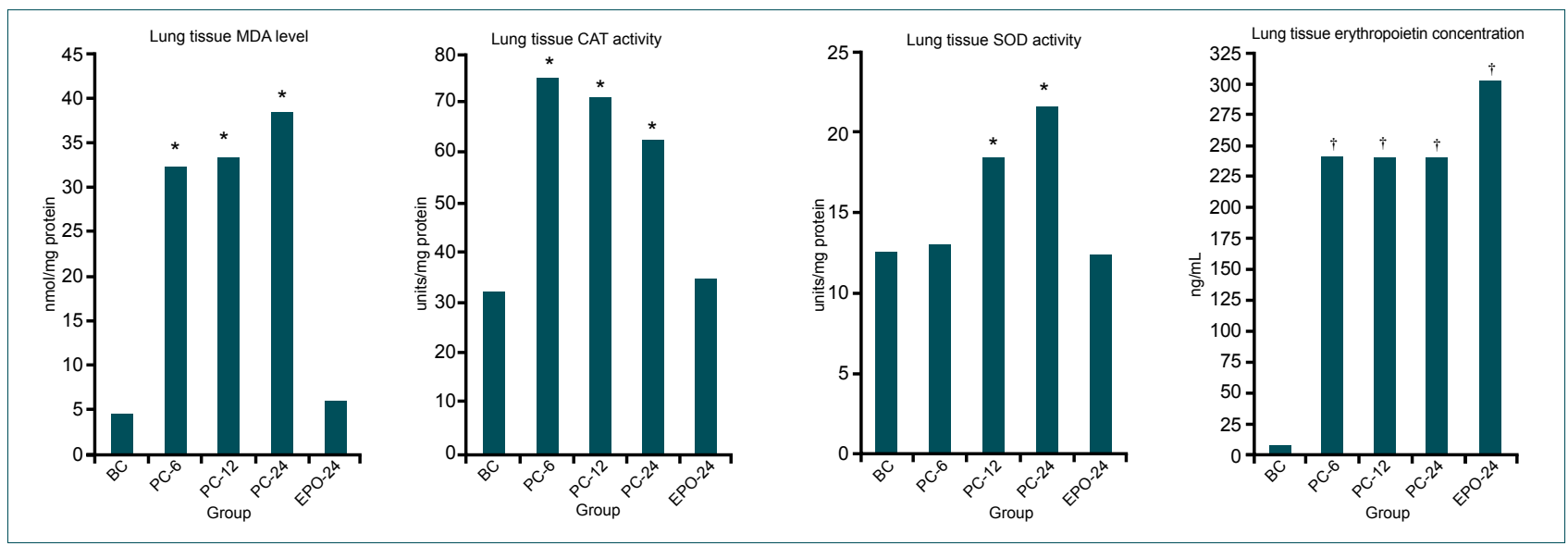

Figure 1. Levels of malondialdehyde and erythropoietin, as well as activity of superoxide dismutase and catalase in rat lung tissue samples among groups. Groups were baseline control: uninjured and untreated; positive control: injured but untreated; and erythropoietin-treated: injured and administered a single dose of intraperitoneal erythro-poietin immediately after lung injury. PC-6, PC-12, and PC-24 were subgroups of the positive control group. ${ }^{*} p<0.005$ vs baseline control and erythropoietin-treated groups. ${ }^{\dagger} p<0.005$ vs baseline control group.

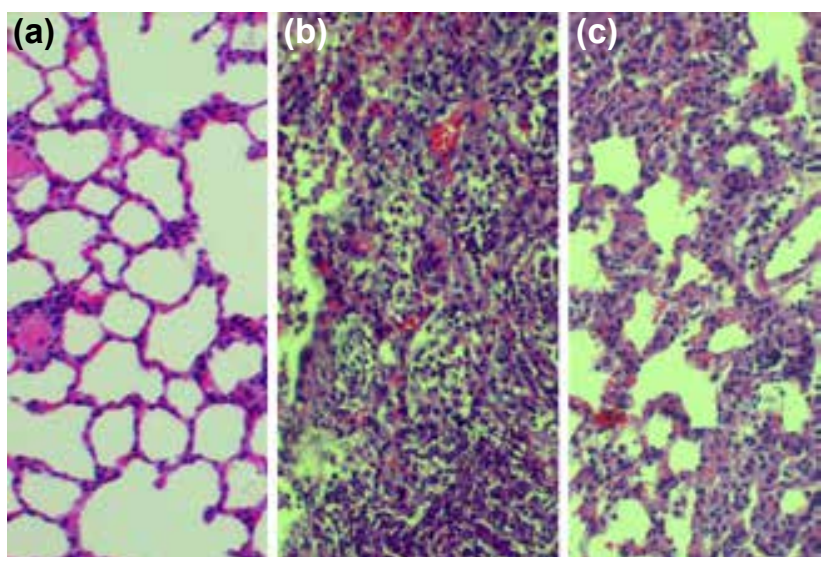

Figure 2. Rat lung histological specimens (all hematoxylin and eosin, $x 100$ ). (a) Normal lung histology in a baseline control rat (no injury, no treatment). (b) Severe tissue inflammation in a positive control rat (injured, no treatment). (c) Mild tissue inflammation in an injured rat treated with erythropoietin.

higher MDA levels in traumatic lung contusion samples, as well as in lung samples following acute lung injury induced by sodium taurodeoxycholate (causing acute necrotizing pancreatitis). Increased EPO concentration in lung tissues was presently ob-served in the first 24 hours after PCn. Because EPO has anti-inflammatory and antioxidant effects, ${ }^{[17-20]}$ levels were analyzed during the early phase of blunt chest trauma. It was de-termined that EPO administration attenuated oxidative stress and inflammation, as evidenced by biochemical and histological parameters. Presently administered was epoetin alfa, a 165 amino acid glycoprotein manufactured by recombinant DNA technology, which has the same biological effect as endogenous human EPO. It has a molecular weight of 30400 $\mathrm{Da}$ and is produced by mammalian cells into which the human EPO gene has been introduced. ${ }^{[5,6]}$

The primary present aim was to determine the EPO level in lung tissue and its relationship with oxidative stress in the first 24 hours of blunt chest trauma - the most critical pe- riod, in terms of morbidity and mortality. For these reasons, EPO concentrations were measured at 6, 12, and 24 hours of blunt chest trauma. To our knowledge, EPO levels have never before been reported in cases of blunt chest trauma, either in animal or human experimental models. It was presently determined that EPO concentrations were elevated in lung tissue of rats sub-jected to blunt chest trauma-induced PCn. Furthermore, it was found that EPO concentrations, as well as antioxidant enzyme (including SOD and CAT) levels, were increased, compared to controls.

EPO exerts its antioxidative effects either directly as a potent free-radical scavenger by the scavenging actions of sugar moieties, or indirectly by increasing the activities of antioxidant enzymes such as SOD, glutathione peroxidase, and CAT. ${ }^{[9,21]}$ Reduced arterial oxygen as-sociated with anemia or hypoxia is the predominant stimulus for EPO production, primarily in the kidneys. On the other hand, EPO is also synthesized in organs such as the liver, spleen, lung, bone marrow, and brain. ${ }^{[5,6]}$ In the present preliminary study, only EPO concentrations in lung tissue were measured, as serum levels could have been affected by other sources of EPO. The present primary limitations were lack of vital signs and oxygenation status measurements. The present study was preliminary, including an evaluation of EPO levels in dam-aged lung tissue, as well as the effect of endogenous EPO in the first 24 hours of lung injury; the present results comprise only preliminary research. Further studies, with similar blunt chest trauma models, are being planned, and with similar parameters, including dosage and timing of administration. It is hoped that all limitations will be addressed in future studies.

Increase in antioxidant enzyme activities, such as SOD and CAT, may indicate failure to compensate for oxidative stress. [18,22] In addition, ROS contributes to intensified synthesis of antioxidant enzymes in tissues, the elevated activity of which may be an adaptive response to oxidative stress. ${ }^{[23]}$ 
Expression of CAT has been reported in alveolar type II cells and macrophages. ${ }^{[18]}$ Increase in CAT activity during hypoxia indicates presence of oxidative stress, and may be an adaptive response aimed to protect mitochondria from elevated levels of $\mathrm{H}_{2} \mathrm{O}_{2} \cdot{ }^{[18,24,25]} \mathrm{CAT}$ is an important intracellular antioxidant enzyme, detoxifying $\mathrm{H}_{2} \mathrm{O}_{2}$ to oxygen and water. A significant increase in CAT production in the $\mathrm{PC}$ group was presumably the result of $\mathrm{H}_{2} \mathrm{O}_{2}$ generation in response to hypoxia. SOD plays an important role in catalyz-ing the conversion of superoxide to $\mathrm{H}_{2} \mathrm{O}_{2}$ and $\mathrm{O}_{2}$, which are then metabolized to water by CAT or other peroxidases. This enzyme has 3 isoforms, and all SODs are highly expressed in the lung tissue, vessels, and airways. However, extracellular SOD activity is reportedly much higher in the lung. ${ }^{[18]}$ Organisms can defend themselves against oxidative stress by increas-ing SOD activity as a protective mechanism. ${ }^{[22,26]}$ In the present study, CAT and SOD ac-tivity levels in EPO-treated animals were close to those of the BC group, which underwent no trauma.

In the present EPO-treated group, the restoration of antioxidant enzyme activity confirms the critical role of EPO in regulating oxidative stress due to blunt chest trauma, and points to its property as a direct, potent free-radical scavenger. Production and secretion of EPO are regu-lated according to the supply of oxygen to the tissues. Hypoxia is the main stimulus for EPO production; in fact, EPO synthesis may increase 50 -fold in severely hypoxic conditions. ${ }^{[5-8]}$ EPO production is induced via hypoxia-inducible factors such as HIF-I, a transcription factor that plays a central role in cellular and systemic homeostatic responses to hypoxia. ${ }^{[5,6,19,20]}$ Hypoxic preconditioning and non-hypoxic inflammatory mediators, including ROS, were found to increase levels of HIF-I. ${ }^{[5-8]}$ Also, hypoxia induces monocyte chemoattractant pro-tein-I (MCP-I) release from alveolar macrophages. MCP-I induces chemotaxis of alveolar macrophages and mast cells. ${ }^{[2,18]}$ HIF-I is involved in transcriptional activation of MCP-I expression stimulated by hypoxia in humans; MCP-I is an HIF-I target gene. Increases in HIF-I and MCP-I were determined in lung homogenates of rats subjected to hypoxia $\left(10 \% \mathrm{O}_{2}\right) \cdot{ }^{[9]}$ One of the primary present findings was that, for the first time, EPO concentrations in lung tissue following blunt chest trauma were much higher, compared to tissue of non-traumatized rats.

Lung tissue is a major site of ROS production. Cells involved also include alveolar macro-phages, neutrophils, mast cells, type II pneumocytes, endothelial cells, smooth muscle cells, and lung fibroblasts. ${ }^{[25,26-30]}$ In inflammatory lung conditions, $\mathrm{H}_{2} \mathrm{O}_{2}$ is primarily pro-duced in alveolar macrophages and neutrophils. ${ }^{[8,29]}$ Alveolar macrophages are directly acti-vated by low oxygen levels. For example, lowering partial pressure of oxygen from 100 to 70 ToR induces a transitory release of $\mathrm{H}_{2} \mathrm{O}_{2}$ into the supernatant of alveolar macrophage cul-tures. [29] Protective properties of EPO have been demonstrated in models of ischemic and inflammatory injury in neuronal, vascular, cardiac, and intestinal tissues. ${ }^{[5,6]}$ However, little is known regarding expression of EPO in pulmonary tissues, or the potential role of EPO in pathological processes of the lung. Recently, EPO and its receptor were found to be expressed in respiratory epithelium. ${ }^{[26]}$ EPO was also found to protect epithelial cells from neutrophil-mediated apoptosis agents. ${ }^{[25]}$ Thus, EPO is thought to have anti-apoptotic and cytoprotec-tive properties in the respiratory epithelium. ${ }^{[9,25]}$

Pretreatment with EPO appears to attenuate I/R-induced lung injury in rats. ${ }^{[9]}$ This ability is at least partially due to EPO's inhibition of the accumulation of polymorphonuclear neutrophils in lung tissue. ${ }^{\left[{ }^{9]}\right.}$ In the present study, CAT activities in the EPO-treated group were similar to those of the BC group, suggesting a lack of polymorphonuclear neutrophil accumulation and/or lack of excessive intracellular $\mathrm{H}_{2} \mathrm{O}_{2}$ accumulation. At 24 hours after contusion in the present study, alveolar edema/congestion and leukocyte infiltration in the lung tissue sig-nificantly increased, but subsided following administration of EPO. EPO most likely acts through a variety of pathways to protect lung tissue against damage from inflammation.

PCn is associated with leukocyte-mediated secondary inflammatory response leading to capil-lary leak, alveolar oedema, and protein extravasation. In addition, histopathological changes are related to severity of the injury. Leukocyte infiltration in the alveolar space and atelectasis have been observed at 24 hours post-contusion. ${ }^{[10,15]}$ In the present study, congestion, hem-orrhage, inflammation, interstitial edema, and alveolar collapse were scored. Total tissue damage score demonstrated significant decrease with the use of EPO. This and other results emphasize the protective effect of EPO on the lungs by reducing inflammation, likely related to anti-inflammatory potential.

In conclusion, endogenous lung parenchyma levels of EPO are elevated following PCn. Ex-ogenous EPO administered after PCn reduced oxidative damage, evidenced histopathological-ly and biochemically. Antioxidant and cytoprotective treatment with compounds such as EPO may contribute to the health of lung tissues following PCn. Further studies of dosage and tim-ing should be performed to clarify underlying mechanisms and maximize the benefit of the protective effect of EPO on lung parenchyma following traumatic injury.

Conflict of interest: None declared.

\section{REFERENCES}

1. Pulmonary contusion in children. http://www.uptodate.com/contents/ pulmonary-contusion-in-children.

2. Hoth JJ, Stitzel JD, Gayzik FS, Brownlee NA, Miller PR, Yoza BK, et al. The pathogenesis of pulmonary contusion: an open chest model in the rat. J Trauma 2006;61:32-45. Crossref

3. Yildirim E, Ozisik K, Solaroglu I, Kaptanoglu E, Beskonakli E, Sargon MF, et al. Protective effect of erythropoietin on type II pneumocyte cells after traumatic brain injury in rats. J Trauma 2005;58:1252-8. Crossref

4. Tkaczyk J, Vizek M. Oxidative stress in the lung tissue--sources of reactive oxygen species and antioxidant defence. Prague Med Rep 2007;108:10514.

5. Jelkmann W. Erythropoietin after a century of research: younger than 
ever. Eur J Haematol 2007;78:183-205. Crossref

6. Brines $\mathrm{M}$, Cerami A. Discovering erythropoietin's extra-hematopoietic functions: biology and clinical promise. Kidney Int 2006;70:246-50.

7. Jones NM, Bergeron M. Hypoxic preconditioning induces changes in HIF-1 target genes in neonatal rat brain. J Cereb Blood Flow Metab 2001;21:1105-14. Crossref

8. Bonello S, Zähringer C, BelAiba RS, Djordjevic T, Hess J, Michiels C, et al. Reactive oxygen species activate the HIF-1alpha promoter via a functional NFkappaB site. Arterioscler Thromb Vasc Biol 2007;27:755-61.

9. Wu H, Ren B, Zhu J, Dong G, Xu B, Wang C, et al. Pretreatment with recombined human erythropoietin attenuates ischemia-reperfusion-induced lung injury in rats. Eur J Cardiothorac Surg 2006;29:902-7.

10. Raghavendran K, Davidson BA, Helinski JD, Marschke CJ, Manderscheid P, Woytash JA, et al. A rat model for isolated bilateral lung contusion from blunt chest trauma. Anesth Analg 2005;101:1482-9. Crossref

11. Fridovich I. Superoxide radical: an endogenous toxicant. Annu Rev Pharmacol Toxicol 1983;23:239-57. Crossref

12. Beutler E. Red cell metabolism: a manual of biochemical methods. 3rd ed. New York: Grune \& Stratton; 1984.

13. Lowry OH, Rosebrough NJ, Farr AL, Randall RJ. Protein measurement with the Folin phenol reagent. J Biol Chem 1951;193:265-75.

14. Ohkawa $\mathrm{H}$, Ohishi N, Yagi K. Assay for lipid peroxides in animal tissues by thiobarbituric acid reaction. Anal Biochem 1979;95:351-8. Crossref

15. Türüt H, Ciralik H, Kilinc M, Ozbag D, Imrek SS. Effects of early administration of dexamethasone, $\mathrm{N}$-acetylcysteine and aprotinin on inflammatory and oxidant-antioxidant status after lung contusion in rats. Injury 2009;40:521-7. Crossref

16. Basaran UN, Ayvaz S, Aksu B, Karaca T, Cemek M, Karaboga I, et al. Desferrioxamine reduces oxidative stress in the lung contusion. ScientificWorldJournal 2013;2013:376959. Crossref

17. Madjdpour C, Jewell UR, Kneller S, Ziegler U, Schwendener R, Booy C, et al. Decreased alveolar oxygen induces lung inflammation. Am J Physiol Lung Cell Mol Physiol 2003;284:360-7. Crossref

18. Mittal M, Siddiqui MR, Tran K, Reddy SP, Malik AB. Reactive oxygen species in inflammation and tissue injury. Antioxid Redox Signal 2014;20:1126-67. Crossref

19. Tabata M, Tarumoto T, Ohmine K, Furukawa $Y$, Hatake $K$, Ozawa $K$, et al. Stimulation of GATA-2 as a mechanism of hydrogen peroxide suppression in hypoxia-induced erythropoietin gene expression. J Cell Physiol 2001;186:260-7. Crossref

20. Chao J, Wood JG, Gonzalez NC. Alveolar macrophages initiate the systemic microvascular inflammatory response to alveolar hypoxia. Respir Physiol Neurobiol 2011;178:439-48. Crossref

21. Fandrey J, Frede S, Ehleben W, Porwol T, Acker H, Jelkmann W. Cobalt chloride and desferrioxamine antagonize the inhibition of erythropoietin production by reactive oxygen species. Kidney Int 1997;51(2):492-6.

22. Chattopadhyay S, Sahoo DK, Subudhi U, Chainy GB. Differential expression profiles of antioxidant enzymes and glutathione redox status in hyperthyroid rats: a temporal analysis. Comp Biochem Physiol C Toxicol Pharmacol 2007;146:383-91. Crossref

23. Komosinska-Vassev K, Olczyk K, Kucharz EJ, Marcisz C, Winsz-Szczotka K, Kotulska A. Free radical activity and antioxidant defense mechanisms in patients with hyperthyroidism due to Graves' disease during therapy. Clin Chim Acta 2000;300:107-17. Crossref

24. Zelko IN, Folz RJ. Extracellular superoxide dismutase functions as a major repressor of hypoxia-induced erythropoietin gene expression. Endocrinology 2005;146:332-40. Crossref

25. MacRedmond R, Singhera GK, Dorscheid DR. Erythropoietin inhibits respiratory epithelial cell apoptosis in a model of acute lung injury. Eur Respir J 2009;33:1403-14. Crossref

26. Folz RJ, Guan J, Seldin MF, Oury TD, Enghild JJ, Crapo JD. Mouse extracellular superoxide dismutase: primary structure, tissue-specific gene expression, chromosomal localization, and lung in situ hybridization. Am J Respir Cell Mol Biol 1997;17:393-403. Crossref

27. Nakanishi K, Tajima F, Nakamura A, Yagura S, Ookawara T, Yamashita $\mathrm{H}$, et al. Effects of hypobaric hypoxia on antioxidant enzymes in rats. J Physiol 1995;489:869-76. Crossref

28. Giles BL, Suliman H, Mamo LB, Piantadosi CA, Oury TD, NozikGrayck E. Prenatal hypoxia decreases lung extracellular superoxide dismutase expression and activity. Am J Physiol Lung Cell Mol Physiol 2002;283:L549-54. Crossref

29. van der Vliet A, Cross CE. Oxidants, nitrosants, and the lung. Am J Med 2000;109:398-421. Crossref

30. Chao J, Wood JG, Blanco VG, Gonzalez NC. The systemic inflammation of alveolar hypoxia is initiated by alveolar macrophage-borne mediator(s). Am J Respir Cell Mol Biol 2009;41:573-82. Crossref

\title{
DENEYSEL ÇALIŞMA - ÖZET
}

\section{Künt göğüs travmasıyla oluşturulan pulmoner kontüzyon sıçan modelinde eritropoietin düzeyleri ve eksojen eritropoietinin etkileri}

\section{Dr. Vedat Bakan, ${ }^{1}$ Dr. Ergül Belge Kurutaş, ${ }^{2}$ Dr. Harun Çıralık, ${ }^{3}$ Dr. Mustafa Gül, ${ }^{4}$ Dr. Ahmet Çelik ${ }^{2}$}

\begin{abstract}
${ }^{1}$ Esenler Kadın Doğum ve Çocuk Hastalıkları Hastanesi, Çocuk Cerrahisi Kliniği, İstanbu
2Sütçü İmam Üniversitesi Tıp Fakültesi, Biokimya Anabilim Dalı, Kahramanmaraş

${ }^{3}$ Sütçü İmam Üniversitesi Tıp Fakültesi, Patoloji Anabilim Dalı, Kahramanmaraş

${ }^{4}$ Sütçü İmam Üniversitesi Tıp Fakültesi, Mikrobiyoloji Anabilim Dalı, Kahramanmaraş
\end{abstract}

AMAÇ: Sıçanlarda oluşturulan künt göğüs travmasına bağı akciğer kontüzyon modelinde, ilk 24 saat içinde endojen eritropoetin düzeylerinin oksidatif stresle ilişkisi ve ekzojen eritropoietinin etkilerini araştırmayı amaçladık.

GEREÇ VE YÖNTEM: Otuz beş sıçan üç gruba ayrıldı: Grup BC (bazal kontrolü, $n=7$ ), herhangi bir işlem yapılmadı; Grup PC (pozitif kontrol, $n=21$ ), sıçanlarda kontüzyon oluşturuldu fakat tedavi verilmedi; Grup EPO-24 (eritropoietin tedavi, $n=7$ ), sıçanlarda kontüzyon oluşturuldu ve künt göğüs travmasından hemen sonra intraperitonal $(5000 \mathrm{lU} / \mathrm{kg})$ tek bir doz eritropoietin verildi. Pozitif kontrol grubu her grupta yedişer sıçan olacak şekilde üç alt gruba ayrıldı (PC-6, PC-12, PC-24). PC-6, PC-12, PC-24 grubundaki sıçanlar, künt travmadan 6, 12 ve 24 saat sonra, EPO-24 ve $B C$ grubundaki sıçanlar ise travmadan 24 saat sonra öldürüldü. Akciğer dokusunda malondialdehit (MDA) ve EPO düzeyleri, süperoksit dismutaz (SOD) ve katalaz (CAT) aktiviteleri ölçüldü. BC, PC-24 ve EPO-24 gruplarında histopatolojik incelemeyle total doku hasarı saptandı.

BULGULAR: Ortalama MDA düzeyleri, SOD ve CAT aktiviteleri BC ve EPO-24 gruplarında $P C$ grubuna göre düşüktü $(P<0.005)$. $P C-6, P C-12$ ve $P C-24$ grubunun ortalama EPO konsantrasyonu BC grubuna göre daha yüksek bulundu $(p<0.005)$. Akciğer doku hasarı skorları EPO-24 grubunda PC-24 grubuna göre daha düşüktü $(p<0.005)$.

TARTIŞMA: Eritropoietin konsantrasyonları, SOD ve CAT düzeyleri pulmoner kontüzyon sonrası ilk 24 saatte akciğer dokusunda yüksek olduğu saptandı. Göğüs travması sonrası akut dönemde uygulanan tek doz intraperitoneal eritropoetin $(5000 \mathrm{IU} / \mathrm{kg})$, travmanın erken döneminde oksidatif hasarı ve doku zedelenmesini azaltmaktadır.

Anahtar sözcükler: Akciğer hasarı; eritropoietin; kontüzyon; oksidatif stres.

Ulus Travma Acil Cerrahi Derg 2016;22(4):322-327 doi: 10.5505/tjtes.2015.09483 